\title{
Research on Skill Testing Standard of Marketing Major of Wuhan City Vocational College
}

\author{
Hui Li*, Huijun Chen \\ Department of Finance and Economics, Wuhan City Vocational College, Wuhan, China \\ Email: *15377015817@163.com
}

How to cite this paper: $\mathrm{Li}, \mathrm{H}$., \& Chen, $\mathrm{H}$. J. (2017). Research on Skill Testing Standard of Marketing Major of Wuhan City Vocational College. Creative Education, 8, 202-209.

https://doi.org/10.4236/ce.2017.82017

Received: December 21, 2016

Accepted: February 5, 2017

Published: February 8, 2017

Copyright $(9) 2017$ by authors and Scientific Research Publishing Inc. This work is licensed under the Creative Commons Attribution International License (CC BY 4.0).

http://creativecommons.org/licenses/by/4.0/

\section{(c) (i) Open Access}

\begin{abstract}
Higher vocational education scale expands rapidly in the recent years, followed by the contradiction between expansion scale and education quality, which has become increasingly prominent nowadays. In order to improve the teaching quality, the most important is to improve daily teaching activity of the harmonious combination of teaching quality monitoring and evaluation system, which focuses on the teaching quality in higher vocational colleges through monitoring and the objective requirement of the long-term quality assurance mechanism. Based on investigation and analysis of present situation, analysis of professional practice skill testing of students majoring in marketing of Wuhan City Vocational College, we develop skill-testing standard in the hope of improving students' marketing professional skills in future.
\end{abstract}

\section{Keywords}

Higher Vocational Colleges, Marketing Major, Skill Testing Standard

\section{Investigation and Analysis of Practical Skills Status of Students Majoring in Marketing of Wuhan City Vocational College}

Higher vocational education emphasizes the cultivation of students' practical skills to provide the practical talents for enterprises need (Zhu, 2015). In order to better solve the problems of present professional practice skills situation of students majoring in Marketing of Wuhan City Vocational College, our research mainly adopts online questionnaire survey, field interviews, telephone interviews and etc. The questionnaire is attached as appendix in the end of this article with survey results. Our research is based on students majoring in Marketing in $\mathrm{Wu}$ han City Vocational College from grade 2014, grade 2015 and grade 2016. We 
totally hand out 500 questionnaires and actually get back 486, recovery rate of which is $97.2 \%$. Survey mainly involves 12 questions related to skill test, such as mode for course-appraisal, the effect of the current evaluation system, learning attitude towards practice skill at school, test mode you prefer when you finish your course, attitudes towards skill test, suggestion for percentage of students joining in skill test, mode and time for skill testing and etc. According to our survey, we can get conclusions as follows: Firstly, the common course-appraisal is still traditional such as closed-book exam and exam in class; secondly, our college students do show enough interest on practical skill testing, and most of students are positive towards practice skill at school; lastly, in order to meet the demand of students, we should improve details of practical skill test as soon as possible, such as percentage of students joining in skill test, mode and time for skill test. Therefore, implement skill test should be urgently needed to improve the teaching effect, thus, skill test standard needs to be developed.

\section{Significance of Implementing Skill Testing in Wuhan City Vocational College}

In view of the survey and analysis of students' professional practice skills of Wuhan City Vocational College, it is necessary to implement skill testing. First, it is necessary to attach importance to practice teaching of teachers because of a shortage of funds of school; second, some teachers still stay in the traditional teaching theory, who are not willing to participate in the practice, thus, their practical skills are poor. With the help of skill testing, school will increase investment in software and hardware, enhance college-enterprise partnership, strengthen teachers' training, supervise and urge teachers to improve practical skills of independent learning. Finally, students will naturally in the usual learning enthusiasm and initiative, so as to improve professional skills. Finally, through skill testing, more communication between colleges from different provinces and cities will be improved.

\section{Literature Review at Home and Abroad}

\subsection{The Foreign Research Status}

Foreign vocational education attaches importance to the cultivation of the students' ability and establishing a set of vocational education patterns, such as the CBE (Competency-Based Education) mode of the United States, dual system of Germany, TAFE (Technical And Further Education) mode of Australia, the GNVQ (General National Vocational Qualification) mode of the UK. Foreign vocational education examination mainly focuses on professional qualification and professional ability appraisal; the examination is mainly closely related to the student's future professional post demand of basic theoretical knowledge, skills, and abilities. Compared to theoretical examination, the assessment of practical ability accounts for a major part. This education examination focuses on skill and ability examination, which is in line with the essence of higher vocational education emphasizing the application and practice. 


\subsection{The Domestic Research Status}

Domestic research on higher education quality monitoring and evaluation system at present is still in the exploratory stage, which has not yet set up a scientific, reasonable and easy-to-operate system (Xiao, 2013). Most of the evaluation attaches more importance to mode than content, to results than process, which did not highlight the comprehensive evaluation of students, thus, to a certain extent weakened the cultivation of student's innovation ability and technical training of professional ability (Chen, 2015). Hunan province has fully implemented multiple professional skill-testing standard since 2010, which reached the aim that promotes study through promoting the teaching purpose and improving relationship between teachers and students, whose experience is worth our reference (Chen, 2013).

\section{Development Principles of "Skill Testing Standard of Marketing Curriculum"}

\subsection{The Scientific Nature}

The law of vocational education and students' cognitive regularity should be followed when skill testing standard is developed. Selection method should be reasonable and should be in line with the practical teaching in vocational colleges (Zeng, 2012). The content of skill testing standard should highlight core skills assessment of professional curriculum.

\subsection{The Development Nature}

Skill testing standard should be proactive, which can reflect technological progress, economic and social development trend, reflect the development trend of professional and vocational education, set aside expanding space for the implementation of the skill testing standard (Li, 2013).

\subsection{The Operation Nature}

Skill testing standard should meet the basic conditions of learning practice of current vocational colleges in our province and improve implementation of professional courses.

\subsection{The Normative Nature}

Technical requirements and professional terms involved in the skill testing standard should conform to state standard or specification, to the requirements of the laws, regulations and relevant documents.

\section{The Design of "Skill Testing Standard of Marketing Curriculum"}

\subsection{The Determination of Evaluation Module}

The determination of evaluation module should be based on the following aspects: Research of companies related to graduates; talent training scheme, course 
system and graduates survey results of marketing major from related colleges; national professional skill appraisal requirements.

\subsection{The Score Proportion Design}

Items of professional courses and professional skills will be sampled from professional morality and behavior as well as operation skill, total score is 100 points (Liu, 2011). It is suggested that scores about professional ethics and behavior account for $20 \%$, scores about operating skill account for $80 \%$. It is suggested that professional course skill sample scores are as follows: $<60$ points, unqualified; 60 - 85 points (including 60 points), qualified; more than 85 points (including 85 points), excellent.

\subsection{Sample Test Paper Design}

It is suggested that professional course skill sample test paper includes two parts: professional morality and behavior (Tang, 2014) as well as operation skill, whose ratio is $2: 8$.

1) Professional morality and behavior.

The main points of this part is students' compliance with laws and regulations, understanding of organization and management concepts, professional role consciousness, service consciousness, consciousness of security, saving consciousness, rigorous and meticulous professionalism and professional etiquette.

2) Operation skill.

The main points of this part is students' professional course knowledge and skill (Nie, 2015), which is divided into three parts: attention, task description and test requirement. The test requirement is divided into technical requirements, professional requirements, testing time requirements. Students will be measured according to the test material and provided professional situations to finish testing tasks.

\subsection{Applied Major and Training Object}

This standard is suitable for students majoring in Marketing from Department of Finance and Economics of Wuhan City Vocational College.

\subsection{Skill Testing Purpose}

Skill testing purposes are as follows: Test students' skills on investigation plan design and writing research report according to the given background; test students' skills on using business negotiation skills and strategy to improve business negotiation according to the business negotiation process (Hou, 2014); test students' skills on fully utilizing marketing strategy to plan and develop the new product promotion, public relations activities, advertising, sales promotion according to the background of the enterprise in accordance with the marketing planning process; test students' skills on using marketing and communication skills for product sales promotion according to the basic requirement for marketing practitioners and standard; test students' customer relationship man- 
Table 1. Development of professional skill sample standard of marketing major.

\begin{tabular}{|c|c|c|c|c|}
\hline Serial number & Development module & Items developed & Items mode & Assessment mode \\
\hline \multirow{3}{*}{1} & \multirow{3}{*}{ Market survey skills sample } & Design of survey scheme & Scheme design & Written test \\
\hline & & Design of survey questionnaire & Questionnaire design & Written test \\
\hline & & Design of market research report & Report design & Written test \\
\hline \multirow[b]{2}{*}{2} & \multirow[b]{2}{*}{ Business negotiation skills sample } & Business negotiation & Scenario simulation & Interview \\
\hline & & Organization of sales promotion & Scenario simulation & Interview \\
\hline \multirow{4}{*}{3} & \multirow{4}{*}{$\begin{array}{l}\text { Marketing planning } \\
\text { skills sample }\end{array}$} & CIS planning & Scheme planning & Written test \\
\hline & & Product planning & Scheme planning & Written test \\
\hline & & Promotion planning & Scheme planning & Written test \\
\hline & & Advertising planning & Scheme planning & Written test \\
\hline \multirow{2}{*}{4} & \multirow{2}{*}{$\begin{array}{l}\text { Customer relationship management } \\
\text { skills sample }\end{array}$} & Customer objection handling & Scenario simulation & Interview \\
\hline & & Customer relations maintenance & Scenario simulation & Interview \\
\hline
\end{tabular}

Note: According to the above-mentioned table, sample test will be combined with "written test and interview".

agement skills (Liu, 2015); in the test, as the above-mentioned skills of students are tested, comprehensive evaluation of students' professional quality in the process of actual operation should also be considered as shown in Table 1.

\section{The Conclusion}

As what has been said above, development of skill testing standard is helpful to guide the college to strengthen professional course construction, make teachers play the subjective initiative, enhance the classroom teaching quality and improve comprehensive quality of college students especially their practical skills. However, for the Hubei province, vocational skill testing system, as a kind of new vocational education teaching quality evaluation system, should be promoted gradually.

\section{Acknowledgements}

This work is supported by School-level Scientific Research Project (Youth Project) of Wuhan City Vocational College in 2016: Research on Skill Testing Standard of Marketing Major of Vocational Colleges [grant No.5]; School-level Teaching and Research Project of Wuhan City Vocational College in 2016: Research on Training Mode Reform of Talents Majoring in Economy and Management of Higher Vocational Colleges under the Background of "Internet +" [grant No. 2016J02]; Industrial-academic-research Project in Colleges and Universities of Wuhan Education Bureau in 2016:

The design and Application of Corporate Identity System Planning [grant No. CXY201633]; Youth innovative project of the 13th Five-Year Plan of CAET in 2016: Research on Creation and Practice of Maker Space Ecological System of Higher Vocational Colleges in Hubei Based on Maker Education [grant No. 
G007].

The authors also gratefully acknowledge helpful comments and suggestions of the reviewers, who have improved the presentation.

\section{References}

Chen, X. (2015). Research on Skill Testing Practice of "Product Sales Promotion" of Marketing Major of Vocational Colleges. Industry and Information Technology Education, 2, 46-50.

Chen, X. (2013). Research on Professional Ability Structure Model Related to Agricultural Trade of Higher Vocational-Take Brokerage and Agency of Agricultural Products Major as an Example. Vocational \& Technical Education Forum, 3, 63-67.

Hou, J. (2014). Exploration and Practice of Professional Core Courses' Skill Testing of Higher Vocational Colleges. Examination Weekly, 79, 5-6.

Liu, Y. (2015). Research on Professional Skill Testing System and Enterprise SkilledTalent Ability Evaluation. Scientific Chinese, 3, 12-13.

Li, X. (2013). Emphasis on Professional Skill Test to Cultivate High Skilled Talents. The Road to Success, 28, 29-32.

Liu, X. (2011). Think of Establishing Teaching Quality Assessment System of Secondary Vocational Colleges. Chinese Vocational and Technical Education, 29, 42-45.

Nie, H. (2015). Think of Skill Test and Professional Construction of Higher Vocational Colleges. Read and Write Periodical, 12, 44.

Tang, D. (2014). Research on Team Construction of Teachers of Higher Vocational Based on Professional Skill Test. Science and Technology, 22, 28-30.

Xiao, W. (2013). Research on Professional Courses Skill Test Evaluation Model in Higher Vocational Colleges. Education Teaching Forum, 12, 280-281.

Zeng, Z. (2012). Research on Professional Skill Test and Professional Quality Cultivation of Higher Vocational Teachers. Entrepreneur World, 10, 15-18.

Zhu, Y. (2015). Vocational Colleges in Hubei Skills Testing System Research. Journal of Shangqiu Vocational and Technical College, 1, 126-128. 


\section{Appendix}

\section{Questionnaire on Practical Skills Training Status of Students Majoring in Marketing of Wuhan City Vocational College}

\section{Dear students:}

In order to better solve the problems of present professional practice skills training situation of students majoring in Marketing of Wuhan City Vocational College Hubei province, we make this questionnaire, hope to hear your valuable advice. The questionnaire is only for research, no other business purposes; we ensure that all information is not outflow.

Thanks to your support and help!

Department of Finance and Economics, Wuhan City Vocational College, 2016.09.08

1. Your gender? A. male B. female Survey result: A. $65.33 \%$ B. $34.67 \%$

2. What is your grade? A. 2016 B. 2015 C. 2014

Survey result: A. $43.25 \%$ B. $34.65 \%$ C. $22.10 \%$

3. What is the mode for course-appraisal in your college?

A. exam in class B. closed-book examC. Skill tests D. Papers or summary report E. other

Survey result: A. $23.35 \%$ B. $60.50 \%$ C. $10.35 \%$ D. $5.8 \%$ E. 0

4. Do you think that the current evaluation system can better promote your learning effect?
A. I think it can best promote my learning effect
B. I think its effect is just so so.
C. I think it has no effect
D. I have another ideas.

Survey result: A.65.37\% B.28.25\% C.5\% D.1.38\%

5 . What is your learning attitude towards practice skill at school?

A. Positive B. Negative C not care

Survey result: A. $73.25 \%$ B. $24.38 \%$ C. $2.37 \%$

6. What kind of test mode do you prefer when you finish your course?

A. Only theory test B. skill test C. theory test and skill test D. else Survey result: A. $22.50 \%$ B.38.15\% B.39.35\%

7. Do you know skill test?

A. Know a lot B know a little $C$ know little $D$ else Survey result: A.27.45\% B.52.35\% C.20.2\%

8. What percentage of students joining in skill test do you suggest?

A. Less than $5 \%$ B. $5 \%-25 \%$ C. $25 \%$ - $45 \%$ D. $45 \%$ - $65 \%$ E. else Survey result: A. $12.25 \%$ B. $20.45 \%$ C.30.15\% D.35.55\% E.1.6\%

9. What mode for skill testing do you suggest?

A. Written test B. computer test C. skill operation D. else Survey result: A. $25.35 \%$ B.24.67\% C.45.24\% D.4.74\% 
10. What do you suggest for skill testing?

A. Professional knowledge test B. comprehensive knowledge test C. skill operation test D. else

Survey result: A. $20.56 \%$ B. $28.57 \%$ C. $38.35 \%$ D. $12.52 \%$

11. How long will you suggest for skill test?

A. An hour or less than an hour B. two hours C. three hours D. four hours E. more than four hours

Survey result: A. $26.86 \%$ B. $51.56 \%$ C. $15.58 \%$ D5\% E 1\%

12. What is your suggestion for skill test in your college?

Submit or recommend next manuscript to SCIRP and we will provide best service for you:

Accepting pre-submission inquiries through Email, Facebook, LinkedIn, Twitter, etc. A wide selection of journals (inclusive of 9 subjects, more than 200 journals)

Providing 24-hour high-quality service

User-friendly online submission system

Fair and swift peer-review system

Efficient typesetting and proofreading procedure

Display of the result of downloads and visits, as well as the number of cited articles

Maximum dissemination of your research work

Submit your manuscript at: http://papersubmission.scirp.org/

Or contact ce@scirp.org 